Kerlin J., Maksymiuk A. (2015). Comparative analysis of the bail-in tool. Copernican Journal of Finance \& Accounting, 4(1), 97-107. http://dx.doi.org/10.12775/CJFA.2015.007

\author{
JaKUb KeRLIN* \\ Warsaw School of Economics
}

\author{
Anna Maksymiuk ${ }^{* *}$ \\ Warsaw School of Economics
}

\title{
COMPARATIVE ANALYSIS OF THE BAIL-IN TOOL
}

Keywords: bail-in, resolution, liquidation of financial entities.

J E L Classification: G21, G33.

Abstract: The article aims to analyse selected components of one of the tools of orderly restructuring and liquidation of financial institutions, namely the conversion of equity or debt write-down tool (bail-in). The presented breakdown shows the variety of approaches to defining bail-in and points of convergence of these approaches. One of the key findings highlights the global shift in the approach to the issue of restructuring and liquidation of financial institutions and indicates a new path undertaken by public authorities, which allows for allocating costs to the owners of financial institutions. Governments should prepare a legal framework for the effective use of this tool before the necessity of its application becomes manifest. The study is based on a comparative review of legal frameworks in selected countries as well as reports, studies, publications and practical experience of countries that have applied bail-in.

Translated by Jakub Kerlin and Anna Maksymiuk

Date of submission: December 23, 2014; date of acceptance: February 12, 2015.

* Contact information: jk43413@sgh.waw.pl, Collegium of Management and Finance, Warsaw School of Economics, Madalińskiego 6/8, 02-513 Warszawa, phone: 605651988. 


\section{INTRODUCTION}

The global financial crisis exposed the deficiencies of regulatory frameworks in many countries. The worsening condition of too-big-to-fail banks in connection with ineffective regulation and supervision (Iwanicz-Drozdowska, Schab 2014) often left no choice for politicians and market supervisors. The only way to overcome the turbulences of the financial distress of that time was recapitalization of financial institutions using public funds as a last resort solution (Mullineux 2013). At the moment of crisis, safety net institutions were not equipped with effective tools, the scope of which would have allowed them to liquidate the financial entity in question in an orderly way without disrupting financial stability. The tools used and interventions of governments in the most turbulent years 2007-09 were very different but the most challenging problem was to find a proper way for the orderly liquidation of large financial entities (Nieto, Garcia 2012). A few governments only announced plans for the development of resolution and recovery laws. Others very rapidly implemented resolution laws within their jurisdictions, tailoring them on an ad hoc basis and for specific needs. Six years after Lehman collapsed, ideas to resolve the problem of too-big-to-fail banks are well-considered, streamlined and presented as an alternative to the infamous bail-out approach. The outcome is a growing number of jurisdictions with bail-in legislation built-in as an integral part of the resolution framework and designed with reference to country specifics (IMF 2012). This has led to the establishment of a new tool in financial architecture, with respect to which a comparative analysis of definitions, triggers, general rules and practical developments for financial institutions are worth studying.

\section{THE RESEARCH METHODOLOGY AND THE COURSE OF THE RESEARCH PROCESS}

The paper is based on descriptive research studies carried out in two main steps. The first step is theoretical and consists of a comparative analysis of legal acts and literature in order to present the current shape of regulations and the approaches to the bail-in tool in selected jurisdictions. The second step is identification of bail-in cases and their practical consequences for owners and creditors. It is based on an analysis of financial documents of safety net institutions (central banks, resolution authorities). The research aims to analyse selected components of the bail-in tool and identify the cases of its application with the consequences for owners and creditors. 


\section{BAIL-IN LEGISLATION \& DEFINITIONS}

The term bail-in is quite new in the vocabulary of economics. Large-scale government support for financial institutions has been called bail-out. In contrast to that process the term bail-in has been established. It has become increasingly popular in financial publications and has been presented to the public as a new model of tool (EC 2011). Academic publications often refer bail-in as a process of bank recapitalization through the mandatory write-down of liabilities or alternatively, the conversion of liabilities to equity (Conlon, Cotter 2014). It makes bail-in one of the resolution tools that can be used to restructure a bank's liabilities. It can be done by converting or writing down unsecured debt without necessitating the institution in question to go bankrupt. In other words, it forces creditors to bear some of the burden of liquidation or restructuring of the financial institution by having a portion of its debt written off or converted to equity (BoE, FDIC 2012).

This mechanism has already been implemented in the laws of several countries and established within their legal frameworks. A summary of legal definitions from selected jurisdictions that have such a definition in place are presented in Table 1. In addition, the definitions of international standard setting bodies have also been included.

Table 1. Summary of the legal definitions of bail-in and bail-in powers

\begin{tabular}{|c|c|c|c|}
\hline Approach & Legal grounds & $\begin{array}{l}\text { Takes effect / } \\
\text { / Established }\end{array}$ & Definition \\
\hline Cyprus & $\begin{array}{l}\text { Law on Resolution } \\
\text { of Credit and Other } \\
\text { Institutions }\end{array}$ & 03.2013 & $\begin{array}{l}\text { The power to: } \\
\text { - write down or convert debt and liabilities into shares } \\
\text { - } \quad \text { reduce (including the reduction to zero), the amount } \\
\text { of debts and liabilities of the institution under reso- } \\
\text { lution } \\
\text { - } \quad \text { cancel financial instruments issued by an institution } \\
\text { - under resolution } \\
\text { - amend the amount of interest payable }\end{array}$ \\
\hline Denmark & Bank Package III & 10.2010 & The force to put losses on senior creditors in bank failures \\
\hline $\begin{array}{l}\text { European } \\
\text { Union }\end{array}$ & $\begin{array}{l}\text { Directive } \\
\text { 2014/59/ EU }\end{array}$ & 01.2016 & $\begin{array}{l}\text { The mechanism for resolution authority to write-down } \\
\text { and convert the liabilities of an institution under resolu- } \\
\text { tion }\end{array}$ \\
\hline
\end{tabular}




\begin{tabular}{|c|c|c|c|}
\hline Approach & Legal grounds & $\begin{array}{l}\text { Takes effect / } \\
\text { / Established }\end{array}$ & Definition \\
\hline $\begin{array}{l}\text { Financial } \\
\text { Stability } \\
\text { Board }\end{array}$ & $\begin{array}{l}\text { Key Attributes } \\
\text { of Effective Reso- } \\
\text { lution Regimes for } \\
\text { Financial Institutions }\end{array}$ & 11.2011 & $\begin{array}{l}\text { The power to: } \\
\text { - write down, in a manner that respects the hierar- } \\
\text { chy of claims in liquidation, the equity or other in- } \\
\text { struments of ownership of the firm, unsecured and } \\
\text { uninsured creditor claims to the extent necessary to } \\
\text { absorb the losses } \\
\text { - convert into equity or other instruments of ownership } \\
\text { of the firm all or parts of unsecured and uninsured } \\
\text { creditor claims in a manner that respects the hierar- } \\
\text { chy of claims in liquidation }\end{array}$ \\
\hline IMF & Discussion note & 04.2012 & $\begin{array}{l}\text { Statutory power of a resolution authority to restructu- } \\
\text { re the liabilities of a distressed financial institution by } \\
\text { writing down its unsecured debt and/or converting it to } \\
\text { equity }\end{array}$ \\
\hline Slovenia & Banking Act & 10.2013 & $\begin{array}{l}\text { A measure to write down or convert bank's qualified lia- } \\
\text { bilities }\end{array}$ \\
\hline $\begin{array}{l}\text { United } \\
\text { Kingdom }\end{array}$ & $\begin{array}{l}\text { Financial } \\
\text { Services Act }\end{array}$ & 01.2015 & $\begin{array}{l}\text { A power to cancel or modify any securities issued by the } \\
\text { bank and to convert any such securities from one form } \\
\text { or class into another }\end{array}$ \\
\hline USA & Dodd Frank Act & 07.2010 & $\begin{array}{l}\text { The power to terminate all rights and claims that the stoc- } \\
\text { kholders and creditors of the financial company may have } \\
\text { against its assets arising out of their status to perform the } \\
\text { obligation that the creditors and shareholders will bear } \\
\text { the losses of financial institution }\end{array}$ \\
\hline
\end{tabular}

S o u r c e : own elaboration based on an analysis of legal acts and reports of international institutions.

Many jurisdictions have developed or are in the process of developing resolution regimes with bail-in tool with no or very limited option of public funding. There are several differences between the definitions of bail-in among the legal frameworks in the presented countries. The most detailed, functional legal definition is present in Cyprus, the most concise has been adopted by Denmark. Taking into consideration their common elements, bail-in seems to be an explicit statutory right (which is also stressed in the IMF definition) that gives almost undisputable power to restructure a bank's liabilities. This restructuring can be of a dual nature, but both are directed against the owners and creditors. It can be done as a conversion of equity or simple writing down (reduction) even to zero of all their rights and claims. It can be applied mainly to unsecured creditors (having no specified assets as collateral) with the maintenance of a hierarchy of claims as for regular liquidation. 


\section{TRIGGERS}

The implementation of bail-in implies serious legal consequences on the situation of many parties and creates new legal relations. Therefore the appropriate legislation quite clearly points out the conditions under which bail-in can be used. Table 2 presents the triggers for the beginning of the resolution process.

Table 2. Bail-in triggers in different jurisdictions

\begin{tabular}{|c|c|}
\hline Approach & Triggers and crucial conditions \\
\hline Denmark & $\begin{array}{l}\text { Resolution (and bail-in as a part of it) can be started when: } \\
\text { - } \quad \text { a bank no longer meets the regulatory capital requirements } \\
\text { - } \quad \text { the deadline for the bank's restoration of the capital was not met }\end{array}$ \\
\hline $\begin{array}{c}\text { European } \\
\text { BRRD }\end{array}$ & $\begin{array}{l}\text { Resolution (and bail-in as the first part of it) can be started, when all of the following conditions are } \\
\text { met: } \\
\text { - the institution is failing or likely to fail } \\
\text { - there is no reasonable prospect that any alternative private sector measures would prevent the } \\
\text { failure of the institution within a reasonable timeframe } \\
\text { - the action is necessary to protect the public interest }\end{array}$ \\
\hline FSB & $\begin{array}{l}\text { Resolution (and bail-in as a part of it) should be initiated: } \\
\text { - when a firm is no longer viable or likely to be no longer viable, and has no reasonable prospect } \\
\text { - } \quad \text { of becoming so }\end{array}$ \\
\hline Slovenia & $\begin{array}{l}\text { The decision on bail-in application may be issued when: } \\
\text { - } \quad \text { the bank is subject to an increased risk } \\
\text { - no circumstances exist to eliminate the increased risk on a timely basis } \\
\text { - } \quad \text { it is not probable that the bank will attain capital and liquidity adequacy within a relevant time } \\
\text { period } \\
\text { - it is in the public interest to prevent instability of the financial system }\end{array}$ \\
\hline $\begin{array}{l}\text { United } \\
\text { Kingdom }\end{array}$ & $\begin{array}{l}\text { The condition to launch bail-in is that the exercise of that power is necessary, having regard to the } \\
\text { public interest in: } \\
\text { - } \quad \text { the stability of the financial systems of the country } \\
-\quad \text { the maintenance of public confidence in the stability of those systems } \\
\text { - the protection of depositors } \\
\text { - } \quad \text { the protection of any client assets that may be affected }\end{array}$ \\
\hline USA & $\begin{array}{l}\text { The competent authority shall determine that such action is necessary for purposes of the financial } \\
\text { stability of the country, and not for the purpose of preserving the covered financial company }\end{array}$ \\
\hline
\end{tabular}

S o u r c e : own elaboration based on an analysis of legal acts and reports of international institutions.

In general, to implement bail-in typically several conditions have to be met. Triggers listed in the table above unambiguously indicate that in order to start a bail-in process, the decision on its application should lie in the public interest, which is the main priority of its use. The definitions among countries tend 
to differ. Some of them concentrate on economic indicators whose source lies within a financial institution itself (e.g. being close to balance sheet insolvency or no chance for private funding, etc.). Others point out the necessity of protection of overall financial stability, which indirectly can be presented as it is in the UK - public confidence, the interest of depositors or financial stability of the country. Attention should also be paid to the US definition contained in the Dodd Frank Act, where it is necessary from the point of view of national stability and not the particular private interest (negative premise). Usually the decision whether to implement bail-in is taken within different jurisdictions by different authorities mandated to do so and the approaches and understanding can vary greatly.

\section{GOALS OF BAIL-IN}

The data presented in the Table 3 precisely describe the reasons for the implementation of bail-in. Several countries like Slovenia or Denmark do not directly state the aims of bail-in in their legislation, which on one hand gives them more flexibility but, on the other, also weaker legal positions. Other jurisdictions tend to be more precise about this issue. Both the Financial Stability Board and the EU Bank Recovery and Resolution Directive pay more attention to recapitalizing and allowing the institution to operate on a "going concern" basis. By means of available measures the viability of a distressed institution should be restored. Other reasons for implementing bail-in, stated in the Dodd Frank Act and the UK's Banking Act, include reducing the risk to financial stability and minimizing the costs for public funds.

Table 3. Goals of bail-in and its main principles

\begin{tabular}{|l|l|}
\hline \hline Approach & \multicolumn{1}{c|}{ Aim of bail-in } \\
\hline \hline Cyprus & $\begin{array}{l}\text { Maximize bail-inable amounts and minimize further capital needs } \\
-\quad \text { Avoid strategic defaults } \\
-\quad \text { Protect covered deposits } \\
-\quad \text { Minimize the possibility of intervention of deposit insurer }\end{array}$ \\
\hline $\begin{array}{l}\text { European } \\
\text { BRRD }\end{array}$ & $\begin{array}{l}\text { To restore entity's ability to comply with the conditions to authorization and to continue to carry out } \\
\text { the activities for which it is authorized and to sustain sufficient market confidence in the institution } \\
\text { or entity }\end{array}$ \\
\hline FSB & Achieving or helping to achieve continuity of essential functions \\
\hline IMF & To achieve a prompt recapitalization and restructuring of the distressed institution \\
\hline
\end{tabular}




\begin{tabular}{|l|l|}
\hline \hline Approach & \multicolumn{1}{c|}{ Aim of bail-in } \\
\hline \hline $\begin{array}{l}\text { United } \\
\text { Kingdom }\end{array}$ & Minimizing recourse to public funds and reducing risks to financial stability \\
\hline USA & $-\begin{array}{l}\text { Avoiding or mitigating serious adverse effects on the financial stability or economic conditions } \\
\text { of the country }\end{array}$ \\
& $-\begin{array}{l}\text { Facilitating the orderly liquidation of the financial company } \\
-\end{array}$ \\
\hline \hline
\end{tabular}

S o u r c e : own elaboration based on an analysis of legal acts and reports of international institutions.

\section{BAIL-IN TOOL PRACTICE}

Although bail-in is not a new concept in the theory of finance, it was applied to financial institutions rather exceptionally (IMF 2014). Therefore practical experience of the write-down and conversion mechanisms in relation to financial institutions is very limited. Table 4 presents the identified cases of application of this resolution tool in the cases of banks in different jurisdictions. The information about the jurisdiction, name of the bank, time as well as the haircut rate is included.

Table 4. Bail-in practical experience

\begin{tabular}{|c|c|c|}
\hline Country & Bailed-in entities and haircut rates & $\begin{array}{c}\text { Name of the bank with the time } \\
\text { of bail-in application }\end{array}$ \\
\hline \multirow[t]{2}{*}{ Cyprus } & $\begin{array}{l}\text { - } \quad \text { shareholders and bondholders (full bail-in) } \\
\text { - } \quad \text { uninsured depositors (haircut } 60 \%)\end{array}$ & $\begin{array}{l}\text { Cyprus Popular Bank } \\
\text { (Laiki Bank) } \\
\text { March } 2013\end{array}$ \\
\hline & $\begin{array}{l}\text { - } \quad \text { shareholders and bondholders (full bail-in) } \\
\text { - conversion of the part of uninsured deposits into equity } \\
\text { (haircut } 60 \% \text { ) }\end{array}$ & $\begin{array}{l}\text { Bank of Cyprus } \\
\text { March } 2013\end{array}$ \\
\hline \multirow[t]{5}{*}{ Denmark } & - lowest ranking equity and liability positions (haircut $41.2 \%$ ) & $\begin{array}{l}\text { Amagerbanken } \\
\text { February } 2011\end{array}$ \\
\hline & $\begin{array}{l}\text { - lowest ranking equity and liability positions (haircut } 26.4 \% \text { ) } \\
\text { - } \quad \text { uninsured retail deposits (haircut 26.4\%) }\end{array}$ & $\begin{array}{l}\text { Fjordbank Mors } \\
\text { June } 2011\end{array}$ \\
\hline & - subordinated capital & $\begin{array}{l}\text { Max Bank } \\
\text { October } 2011\end{array}$ \\
\hline & $\begin{array}{l}\text { - the negative difference between the assets and all liabilities } \\
\text { was paid by the deposit insurer in full (deposit insurance fund } \\
\text { in lieu of a part of the creditors) }\end{array}$ & $\begin{array}{l}\text { Sparekassen } \varnothing \text { stjylland } \\
\text { April } 2012\end{array}$ \\
\hline & $\begin{array}{l}\text { - the negative difference between the assets and all liabilities } \\
\text { was paid by the deposit insurer in full (deposit insurance fund } \\
\text { in lieu of a part of the creditors) }\end{array}$ & $\begin{array}{l}\text { Spar Salling Sparekasse } \\
\text { April } 2012\end{array}$ \\
\hline
\end{tabular}




\begin{tabular}{|c|c|c|}
\hline Country & Bailed-in entities and haircut rates & $\begin{array}{l}\text { Name of the bank with the time } \\
\text { of bail-in application }\end{array}$ \\
\hline \multirow[t]{2}{*}{ Iceland } & $\begin{array}{l}\text { - non-Icelandic retail depositors (haircut } 100 \% \text { but fully cove- } \\
\text { red by foreign deposit insurers) }\end{array}$ & $\begin{array}{l}\text { Landsbanki } \\
\text { October } 2008\end{array}$ \\
\hline & $\begin{array}{l}\text { - } \text { non-Icelandic debt holders (haircut } 100 \% \text { ) } \\
\text { - } \text { non-Icelandic depositors (haircut } 100 \% \text { but fully covered by } \\
\text { foreign deposit insurance funds) }\end{array}$ & $\begin{array}{l}\text { Kaupthing Edge } \\
\text { October } 2008\end{array}$ \\
\hline \multirow[t]{3}{*}{ Kazakhstan } & $\begin{array}{l}\text { - } \quad \text { foreign bondholders (haircut } 45 \% \text { in 2009) } \\
\text { - } \quad \text { local bondholders (haircut } 55 \% \text { in 2012) } \\
\text { - } \quad \text { state deposits partially converted into equity }\end{array}$ & $\begin{array}{l}\text { BTA Bank } \\
\text { February } 2009 \\
\text { March } 2012\end{array}$ \\
\hline & $\begin{array}{ll}\text { - } & \text { bondholders } \\
\text { - } & \text { unsecured creditors (haircut } 76 \%)\end{array}$ & $\begin{array}{l}\text { Alliance Bank } \\
\text { June } 2010\end{array}$ \\
\hline & - unsecured creditors (haircut 41\%) & $\begin{array}{l}\text { Temirbank } \\
\text { October } 2009\end{array}$ \\
\hline \multirow[t]{2}{*}{ Slovenia } & $\begin{array}{l}\text { - } \text { share capital and subordinated liabilities (full bail-in) } \\
\text { - } \quad \text { conversion of a hybrid instruments into ordinary shares }\end{array}$ & $\begin{array}{l}\text { Nova Ljubljanska Banka } \\
\text { January } 2013\end{array}$ \\
\hline & $\begin{array}{l}\text { - } \quad \text { shareholders and bondholders (full bail-in) } \\
\text { - } \quad \text { state deposits partially converted into equity }\end{array}$ & $\begin{array}{l}\text { Nova Kreditna Banka Maribor } \\
\text { April } 2013\end{array}$ \\
\hline RSA & $\begin{array}{l}\text { - } \quad \text { subordinated debt and shareholders (haircut 10\%) } \\
\text { - } \quad \text { wholesale depositors (haircut } 10 \% \text { ) }\end{array}$ & $\begin{array}{l}\text { African Bank } \\
\text { August } 2014\end{array}$ \\
\hline
\end{tabular}

S o u r c e : own elaboration based on BFG, IMF, WB (2014).

The bail-in approach varies in the cross-country evidence study but the specificity of its application is similar. Usually the bail-in tool was applied in jurisdictions were a systemic crisis in the banking sector was present. Frequently it was connected with a bad situation of the whole sector in the country (however, the Republic of South Africa is an exception). Although bail-in legislation is present in many jurisdictions, the contemporary practice of the application of bail-in is so-far the most popular in Europe, where Denmark seems to be the country with the most developed practical experiences.

Jurisdictions are characterized by a different hierarchy of claims, which sets the order of the writing down of creditors. However, as a rule, shareholders and bondholders seem to be the first category of creditors taken into consideration to be affected by bail-in, depending on whether the bondholders were secured or not. A separate issue is differentiation of the situation of creditors done on the basis of nationality, which took place in Kazakhstan and Iceland. The most wellknown cases of bail-in are those from Cyprus and Iceland. It can be assumed that as long as bail-in impacts the interests of narrow groups and does not af- 
fect covered depositors, it is publicly accepted. When the proposal to also bail-in depositors is under consideration (as it was in these two jurisdictions) it seems to be very problematic and leads to numerous disputes (Méndez Pinedo 2001).

It is difficult to find criteria which clearly settle whether bail-in was a success or not due to the application of this tool in different conditions and usually in tandem with other resolution tools. Among the jurisdictions were bail-in was applied two groups can be distinguished. The first is a group were the bailin law was introduced ad hoc, when it was the only way to resolve the situation. It was associated with problems relating to bank panic (Cyprus, Iceland) and met with criticism of the international community (South Africa), because it not always went in parallel with the agreed international standards. Although there were some distortions, Cypriot, Icelandic and Kazakh bank bail-in cases ended with moderate bail-in success. What is important is that it allowed for continuity of critical functions of financial institutions as well as shifting part of the recapitalization costs to bank creditors. The second is a group with well-prepared bail-in, with a strong legal framework and public authorities equipped with a full suite of administrative tools. So far this took place in Denmark or Slovenia and allowed for the smooth finalizing of the bail-in process with better restructuring results. These countries also had lower haircuts because they used more sophisticated supporting tools that allow deposit insurers to bear some losses of restructuring in lieu of some creditors. Although the legal frameworks of the jurisdictions provide for bail-in and usually the rule of no creditor worse off, because of the harsh effect for owners and creditors it seems to be very controversial and often related to expropriation (IBA 2010).

Bail-in was applied to only few banks in several jurisdictions and its longterm economic consequences remain largely unknown. On one hand, bail-in seems to work the best when only idiosyncratic risk materializes and when the contagion risk is low. In the massive loss allocation need (e.g. case of Cyprus or Iceland) bail-in could lead to the new, not explored economic problems as e.g. rapid change of the ownership of the major stake in the banking industry in the country. Moreover, imposing large haircuts on the creditors at one time can lead to the systemic panic, domino effect and accelerates the potential crisis (Goodhart, Avgouleas 2014). On the other hand existence of bail-in lead to incentivization of creditors to monitor the risk of the financial institution, which positively influence the market discipline. Bail-in also allows allocating the costs of bank failures to where they best belong (unsecured creditors and bank shareholders). There are also positive empirical results delivered by a study, which 
retrospectively tested current European bail-in rules by applying them to the conditions of recent global financial crisis (Conlon, Cotter 2014). Although Eurozone banks would have required equity write-downs to cover impairment losses, the projected bail-in capitalization would be sufficient and e.g. depositors would not have experienced any write-downs. Because bail-in is largely untested, the unequivocal assessment is impossible and requires further investigation and study.

\section{SUMMARY}

There have been several important factors that have led to the implementation of bail-in. This resolution tool can be used to recapitalize an institution or entity while maintaining the continuity of provisions of systematically important financial services or to liquidate it in an orderly way. Moreover, it also allows the allocation of losses to bank owners and unsecured and uninsured creditors first. Due to this resolution tool, the reliance on public support can be diminished. Because of its nature, and the harsh consequences for owners and creditors, the optimal approach to bail-in is the subject of debate.

In theory bail-in is believed to be a powerful resolution tool that will reduce the social cost and the disruption to markets in case of bank's failure. It is an answer to the public need of not using taxpayer money in order to terminate the activity of a financial institution. It is presented as an alternative. The dominant concept deriving from definitions or bail-in triggers in legislation shows that bail-in is believed to be a resolution tool of early intervention, applied before an institution becomes insolvent. In legal frameworks it is also designed as a tool that cannot be omitted and is communicated as inevitable for owners and creditors.

Financial institutions will have to take into consideration that simple bail-outs, according to recent changes in the legal framework, will no longer be a widely used tool. The decision on incorporating bail-in into the legal framework in many countries has already been made. The deployment of public money will be done together with bail-in, so its effects can be positive only for protected creditors (e.g. depositors). However bail-in seems to be largely untested and applied in practice in only a few countries, with mixed results, though there is a preponderance of positive outcomes. Introduction of bail-in brings new economic perspective of the functioning of the bank industry but it is too early to reliably point out the practical conclusions. From today's perspective it is too soon to decide whether it will be used on a regular basis within resolution or whether a bail-out policy with the application of other resolution tools will prevail.

\section{REFERENCES}

BoE (2011), Financial Services Act.

Bank of Slovenia (2013), Banking Act.

BFG (2014), High Level Seminar on Bail-in and Deposit Insurance System Interaction, Warsaw. 
BoE, FDIC (2012), Resolving Globally Active, Systemically Important, Financial Institutions.

Central Bank of Cyprus (2013), The Resolution of Credit and other Institutions Law.

CFCT (2010), Dodd-Frank Wall Street Reform and Consumer Protection Act.

Conlon T., Cotter J. (2014), Eurozone Bank Resolution and Bail-In - Intervention, Triggers and Writedowns, European Banking Union: Prospects and Challenges, University of Buckingham, 21-22 November 2014. http://dx.doi.org/10.2139/ssrn.2548770.

EC (2011), Discussion paper on the debt write-down tool - bail-in.

EC (2014), Bank Recovery and Resolution Directive.

Finanstilsynet (2010), Danish Act on Financial Stability.

FSB (2011), Key Attributes of Effective Resolution Regimes for Financial Institutions.

Goodhart Ch., Avgouleas E. (2014), A Critical Evaluation of Bail-ins as Bank Recapitalisation Mechanisms, CEPR, Discussion Paper 10065.

IBA (2010), Report of the International Bar Association in connection with legal issues arising in relation to proposals for bank "bail-in" measures.

IMF (2012), From Bail-out to Bail-in: Mandatory Debt Restructuring of Systemic Financial Institutions, SDN/12/03.

IMF (2014), From Fragmentation to Financial Integration in Europe, Washington.

Iwanicz-Drozdowska M., Schab I., (2014), Capital Regulation of G-SIBS: Does One Size Fit All?. http://dx.doi.org/10.2139/ssrn.2450529.

Méndez Pinedo M. E., (2011). Iceland and the EU: Bitter Lessons after the Bank Collapse and the Icesave Dispute. Contemporary Legal and Economic, Issues III, 9-43, Croatia.

Mullineux A. (2013). Banking for the public good. International Review of Financial Analysis. http://dx.doi.org/10.1016/j.irfa.2013.11.001.

Nieto M. J., Garcia G. G. (2012). The insufficiency of traditional safety nets: what bank resolution fund for Europe?. Journal of Financial Regulation and Compliance, 20 (2), 116-146. http://dx.doi.org/10.1108/13581981211218261. 